\title{
Research on the Functional Orientation of Accounting Innovation Network Subject and Network Operation Mechanism
}

\author{
Jing Ning, ${ }^{*}$ and Wei Wei
}

\author{
${ }^{1}$ School of Economics and Management Beijing Jiaotong University Beijing, China \\ ${ }^{2}$ School of Economics and Management Beijing Jiaotong University Beijing, China \\ *Corresponding author. Email: nj18345177570@163.com
}

\begin{abstract}
New era for the development of high quality accounting industry requirements, make the accounting industry is facing new challenges, and as to improve the quality of accounting, one of the effective means of improving the efficiency of accounting accounting innovation play an irreplaceable role in them, because of the existing literature focuses on the concept innovation, or a fine under the classification of accounting innovation methods research, few of accounting innovation main body should play the role of and coupling mechanism is discussed, thus to make up for the blank, this paper introduce the theory of innovation network accounting innovation to study accounting innovation main body function and operating mechanism. The significance of this study is to provide a new perspective and focus for the innovative development of the accounting industry, to provide more means to solve the problem of accounting development, in order to promote the accounting reform to improve the quality and efficiency of accounting.
\end{abstract}

Keywords: Innovation Nnetwork, Accounting Iinnovation, Operation Mmechanism.

\section{INTRODUCTION}

At present, China's economic development has entered a new era. The convening of the 19th National Congress of the COMMUNIST Party of China (CPC) has highlighted the requirements for high-quality development of China's economy. As an important part of economic management, accounting has become the focus of industry discussions on how to keep pace with The Times and meet the demand for high-quality development of social economy. From quantity to quality, accounting industry is facing new opportunities and challenges.

In December 2018, the Annual conference of Chinese Accounting Association for Higher Engineering Institutions pointed out that "accounting innovation has become an inevitable choice.for high-quality economic development in the new era [1]. At the 2018 academic seminar, the Professional Committee of Basic Accounting Theories of Chinese Accounting Association emphasized: "We must realize the impetus and impact of new changes in accounting environment and new requirements of accounting practice on basic accounting theories, and promote the improvement and innovation of basic accounting theoretical system [2]. Sun Zheng and Liu Fengwei proposed that "reform and innovation are the main melody of the future development of accounting [3]". It can be seen that the innovative development of accounting industry is imperative.

So how should accounting profession innovate? Most of the existing literature focuses on the study of accounting innovation concepts or accounting innovation methods under a specific classification. For example, Li Yujie points out that "the theoretical innovation of accounting should be combined with the characteristics of the information economy era [4]. Feng Qiaogen proposed that "the theory and method of supply-side reform should be embedded into the practice of management accounting to realize the innovation of management accounting [5]." Wu Taki proposed to "construct a new mode of human resource accounting through accounting theory innovation [6]." Chen Donghua believes that "not only the conceptual framework of accounting itself should be innovated, but also the possibility of innovation in accounting system should be found with the development of network technology [7]. Ding Shenghong and Wu Yingyu explored the theoretical basis of management accounting theory and method innovation based on humanistic economic development concept [8]. Current research focuses on what accounting innovation should do, while ignoring who should do it and how. Therefore, in order to make up the gap of literature research, this paper introduces the theory of innovation network on the basis of the existing research on accounting innovation, aiming to build the innovation network of 
accounting subject, and discusses the process and transmission mechanism of its influence on accounting reform from the perspective of accounting innovation subject. The fundamental purpose of the research is not only to supplement the existing literature, but also to provide a new perspective and trigger new thinking.

\section{THE MAIN BODY AND FUNCTION ORIENTATION OF ACCOUNTING INNOVATION NETWORK}

The theory of innovation network is mostly applied in industrial clusters and enterprise management. Freeman first put forward the concept of innovation network. He pointed out that innovation network is a basic institutional arrangement to deal with systematic innovation, and its main linking mechanism is the innovation cooperation relationship between enterprises. [9] this paper argues that the innovation network theory is used in the enterprise management research is much, but in fact it has a strong universality, in recent years a large number of scholars introducing the theory of agricultural science and technology innovation, to explore the agricultural science and technology innovation main body function orientation and operational mechanisms, such as Liu Zhenbin, yi-fang zheng using the theory of innovation network positioning the main body of agricultural science and technology innovation, and its main body role [10]. Wang Nong, Zhou Li, Wang Yue-hua et al. introduced it to study the driving mechanism of collaborative innovation of agricultural scientific research [11]. Zhang Jingrui and Liu Xinling used this theory to discuss the movement mechanism and path selection of innovation [12]. The above research indicates that the innovation network theory has certain reference value and significance in exploring the function and operation mechanism of the innovation subject. Therefore, this paper is introduced into the accounting industry for preliminary exploration and analysis.

Innovation network can be divided into horizontal mode and vertical mode. Horizontal mode, such as industry-University-Research collaborative innovation network, emphasizes the collection and joint action of all influencing factors. The vertical model, such as industrial cluster collaborative innovation network, is more inclined to the function of the industry or its own conditions. Combined with the characteristics of the accounting profession, this paper selects the horizontal mode to discuss the function positioning and the role of the main body of each factor in the process of accounting innovation.

Accounting innovation refers to the activities of accounting personnel and other related personnel to effectively solve the existing problems in the accounting practice of enterprises by creating or improving the original accounting concepts, theories, technologies, laws, regulations, systems and other accounting norms in the current accounting environment and conditions. The author believes that the body of the impact on accounting innovation process shall be included in the accounting innovation network, due to the existing literature on accounting innovation main body blank in the research of classification, this paper reference implementation main body of the study of accounting related services path classification [13-14] will be the main body of accounting innovation network points below are five categories, respectively, for the government, universities and research institutions and accounting institute, accounting firms, accounting personnel.

\section{(1) Government}

Government plays the role of guide, supervisor and creator in the innovation network.

Government is the main body of policy innovation, in today's booming economy environment, the government should rely on policies such as reform of supply side, "area" development opportunity timely introduction and more advanced accounting concept, technology, products, promote the innovation of accounting, the accounting policies, guidelines, development goal in the process, in close connection with the development of China's accounting profession characteristic, to control the direction of innovative development. Actively encourage scientific research institutions, accounting associations and other trade organizations, accounting firms and accounting service personnel to innovate accounting concepts and update their business skills, so as to provide a good platform for the communication and development among various subjects. Therefore, the government plays an irreplaceable guiding role in the innovative development of the accounting industry.

The government is also the innovation network supervisors, good market environment is the prerequisite for innovation, form a good market structure through policy adjustment, build and perfect the relevant laws and regulations, accounting industry restrain improper accounting market competition, increase the input to the accounting profession, and promote the healthy development of the accounting industry in our country. All these provide a good development environment for the innovation of accounting industry.

\section{(2) Universities and Research Institutions}

In the accounting innovation network, colleges and universities are the main force of knowledge innovation, dissemination and training of innovative talents, as well as the supporting foundation and important army of accounting innovation. Colleges and universities can provide accounting industry with high-quality talents, 
accounting innovation technology achievements and knowledge.

As a talent training base, colleges and universities rely on their educational advantages to cultivate innovative talents meeting the market demands. With the development of The Times, professional skills are no longer the only criteria for judging talents, and innovative thinking ability will stand out. How to establish innovative talent training mode is an urgent problem for colleges and universities. Chongqing university of science and technology field and TaoYan xin, studied the schools, teachers, students, community four dimensions influence on students' innovative entrepreneurship education, and the value driving factors of four dimensions, in practical application, for logic main line, discusses the integrated innovation MPAcc training system of entrepreneurship education reform and optimization strategy, aims to frost, Cheng Ping to chongqing university of science and technology of machine learning and intelligent accounting course as an example, based on JiTT pattern design of the "Internet + accounting" MPAcc course teaching. These innovative educational models should be popularized and applied vigorously. The accounting profession not only needs the talented person but also needs the innovative talented person, the traditional pattern breaking also must rely on the innovative strength.

While cultivating talents, colleges and universities are also platforms for accounting research. The research and development of relevant accounting projects requires the joint efforts of university researchers, and the university should actively provide guidance and technical support for the exploration of innovative projects. Many colleges and universities have introduced high and new technologies into accounting management and made remarkable theoretical achievements in the process of in-depth research. However, relevant achievements are still limited to the theoretical field and have not been applied into practice. Therefore, colleges and universities should actively encourage researchers to apply accounting innovative achievements into practice.

At the same time, due to the full range of professional disciplines and rich structural levels in colleges and universities, it is conducive to mutual support, crossover and penetration, and the production of new academic ideas and scientific achievements; For example, the combination of accounting and information technology makes the accounting industry have a solid technical support in the Internet era.

Colleges and universities provide inexhaustible inspiration and impetus for the innovative development of the accounting industry and play a unique role in the accounting innovation network.

\section{(3) Accounting Institutes}

While the government and colleges and universities play their roles, accounting institutes should also play an important role in promoting accounting innovation. Accounting society has the role of theory guide, policy publicity, knowledge dissemination, talent discovery, is the bridge and link between government agencies, business and academia, accounting elite exchange on accounting innovation and development and practice of high-level platform.

Accounting institutes plays an important role in the innovation network of closely linking the main bodies

First of all, the accounting institutes can organize and coordinate the national accounting scientific research force, carry out accounting theoretical research and academic exchanges, promote the promotion and application of scientific research results, make the innovative development of the accounting industry targeted, and play a guiding role in the subdivision of professional fields under the guidance of the government. Secondly, accounting work and accounting education experience summarized by the accounting institutes in China provide an auxiliary role for the research of accounting projects and the promotion of accounting education reform in colleges and universities. The accounting journals, monographs and data edited and published by him have laid a theoretical foundation and provided intellectual support for the innovation and development of the accounting industry. At the same time, giving full play to the advantages of industry group intelligence, to carry out multi-level, many forms of intelligence service, including cultivating senior accounting staff, accounting and accounting consultancy and training services, etc., for certified public accountants and accounting of enterprise service personnel to provide professional learning stage, and cultivate the innovative concept of accounting service personnel; Thirdly, the international academic exchanges and cooperation in the field of accounting led by the institute will introduce foreign advanced accounting research toChina, so as to better withstand the impact and grasp the opportunities of the accounting industry in the tide of globalization.

\section{(4) Accounting Firms}

Accounting firm is platform for accounting talents to be further cultivated. At present, China's accounting firms still have some problems, such as small scale, imperfect management system and salary system, and there is still a long way to go with the mature foreign firms, but this is also a good time for their reform and development. Attach importance to the development environment and salary and welfare of accounting talents, explore innovative distribution and incentive mechanism for retaining high-end accounting talents and flow mechanism for accounting talents, strengthen 
the improvement of the quality of existing personnel, and establish a long-term talent training system. It is necessary for the accounting firm to introduce advanced accounting concepts, provide high-quality accounting services and stimulate the creativity of accounting staff.

Accept and practice innovative accounting products, make full use of advantages in providing accounting services, carry out the concept of innovative development while expanding business scope and business fields, and strive to build a brand of domestic capital with core competitiveness.

The deepening of economic globalization, the accounting industry in our country at the same time, by the impact of the internationalization of foreign advanced system model also provides a train of thought for accounting innovation, accounting firm is the backbone of accounting innovation, is the first to hit also plays the role of the most easy to change to change, is the main force of accounting innovation network, we must not ignore the role in the accounting innovation network.

\section{(5) Accounting Personnel}

Accounting personnel themselves are not only accounting innovators but also the recipients of innovative concepts or products, and they have an inescapable important responsibility for the innovation of accounting concepts and products.

Accounting service personnel must have international vision, innovative strategic vision, open acceptance consciousness, cooperation and inclusive quality. Under this premise, accounting service personnel can accept and provide innovative accounting service products. The requirements of the accounting industry with each passing day, the accounting staff should be paid attention to in cultivating and improving their comprehensive ability, should fully understand the current market demand, constantly update their knowledge structure, cultivate creative thinking at the same time should keep in mind the "four spirit of" dedication, professional, professional and entrepreneurial spirit, strive to make itself become an irreplaceable core talents in the industry. Provide manpower support for the innovation and development of accounting profession.

The innovation of accounting industry is the innovation of accounting personnel in the final analysis, and the construction of accounting innovation network depends on the joint efforts of accounting service personnel.

\section{THE OPERATING MECHANISM OF ACCOUNTING INNOVATION NETWORK}

This paper holds that the accounting innovation network mainly includes five main bodies: government, universities and research institutions, accounting institutes, accounting firms and accounting personnel. The government guides the development of accounting innovation by making policies, regulating the market environment, creating an innovative atmosphere, and guiding the innovation direction of the accounting industry. Accounting firms are not only the implementers of accounting innovation decisions but also the biggest beneficiaries. The accounting institutes are the link that provides a docking platform for accounting service personnel and accounting innovation projects. Universities and research institutions are the research subjects of exploring accounting innovation and the training subjects of accounting innovation personnel. Accounting personnel are the actual operators and promoters of accounting innovation products. Universities and research institutions, accounting firms and accounting personnel constitute the core network of accounting innovation, in which the government and industry organizations play an auxiliary and catalytic role. [5] The five influence and promoteeach other, and the internal relationship is shown in the figure below:

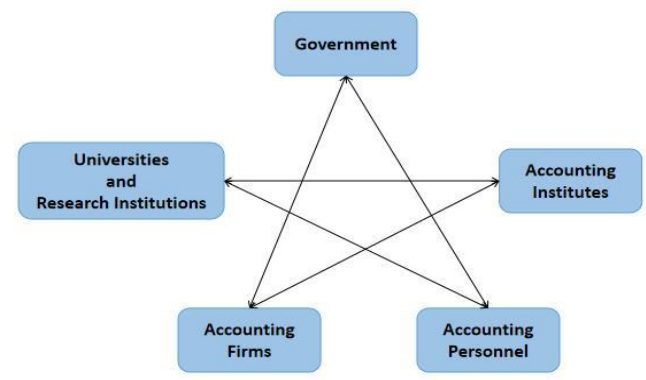

Figure 1 Accounting innovation network.

The accounting innovation network mainly covers three support systems. The first is talent support, which refers to the talent support provided by accounting firms, universities and research institutions accounting institutes, the second is the content and products of accounting innovation, such as accounting innovation concept, theory, technology and other innovative product support. The third is the innovation environment, which is mainly the policy environment, market environment, laws and regulations that influence accounting innovation. The three support systems combine the main bodies closely together and provide strong intellectual support for the innovation and development of the accounting industry.In order to make the mechanism of accounting innovation network more concrete and show its detailed interaction, this paper refers to the theory of system dynamics, based on the functional positioning between the innovation subjects, to build the dynamic factor diagram of accounting innovation network. As an important simulation tool of collaborative innovation system, 
factor diagram can simulate the specific feedback structure between dynamic elements.

It can be seen from the internal relationship between accounting innovation subjects that the whole system dynamic system starts from the government and finally returns to form multiple feedback loops. Taking "government - accounting firm","government universities and research institutes - accounting firm" and "government - universities and research institutes accounting firm" as examples, this paper further discusses the operating mechanism of accounting innovation network.

1) "Government-Accounting Firms" power system feedback loop

The government spending on market regulation to promote the improvement of the relevant policies and regulations, for certified public accountants provide good market environment, innovation atmosphere for its innovation and development of a sound legal basis, the innovation and development of the public accounting firms and cause accounting change, the accounting change will cause the accounting quality and efficiency of generating economic value, make up the fiscal spending, a virtuous circle.

2) The power system feedback loop of "Government - Universities and Research Institutions - Accounting Firms"

The government promotes the development of projects and the cultivation of innovative talents through investment in universities and research institutions. On the one hand, the development of innovative projects and the cultivation of innovative talents will promote the accounting reform; on the other hand, the application of innovative projects by accounting firms to absorb innovative talents will enhance the innovation ability and further promote the accounting reform.

3)"Government - Accounting Institute - Accounting Firm" dynamic system feedback loop

The government promotes platform exchange opportunities through policy support for project exchange of accounting Institute, promotes further promotion of relevant innovative ideas, and enables accounting firms to timely understand and adopt advanced ideas and technologies to enhance innovation ability, thus providing dynamic support for accounting reform.

As mentioned above, the most representative three dynamic feedback loops are listed. The other loops have similar overlap with the above functional processes, so it will not be repeated here. The formation of dynamic element system is inseparable from the role of each subject, clear subject positioning, ensure the function play, is the necessary way to realize the accounting innovation network.

\section{CONCLUSION}

In recent years, with the rapid development of the economy, high-quality accounting work has been from the choice of products into a necessity. As to improve the quality of accounting, one of the most efficient means to enhance the efficiency of the accounting of accounting innovation is becoming more and more cause the attention of people, the essence of accounting innovation network is established in this paper to integrate all the principals within the network resources, give full play to the ability and the effectiveness of each subject in order to improve the efficiency and quality as the theme, finally have the effect of $1+1>2$, to enhance the level of the innovation of the accounting industry to promote the accounting change. Due to the lack of existing literature, this paper focuses on the functional orientation and network operation mechanism of accounting innovation subjects, in order to lay a good foundation for future research. There are still many shortcomings in this paper, for example, the division of accounting innovation subjects is subjective to a certain extent, there is no further exploration of the specific operation mode of accounting innovation network, etc., and the follow-up research will further explore this aspect. 


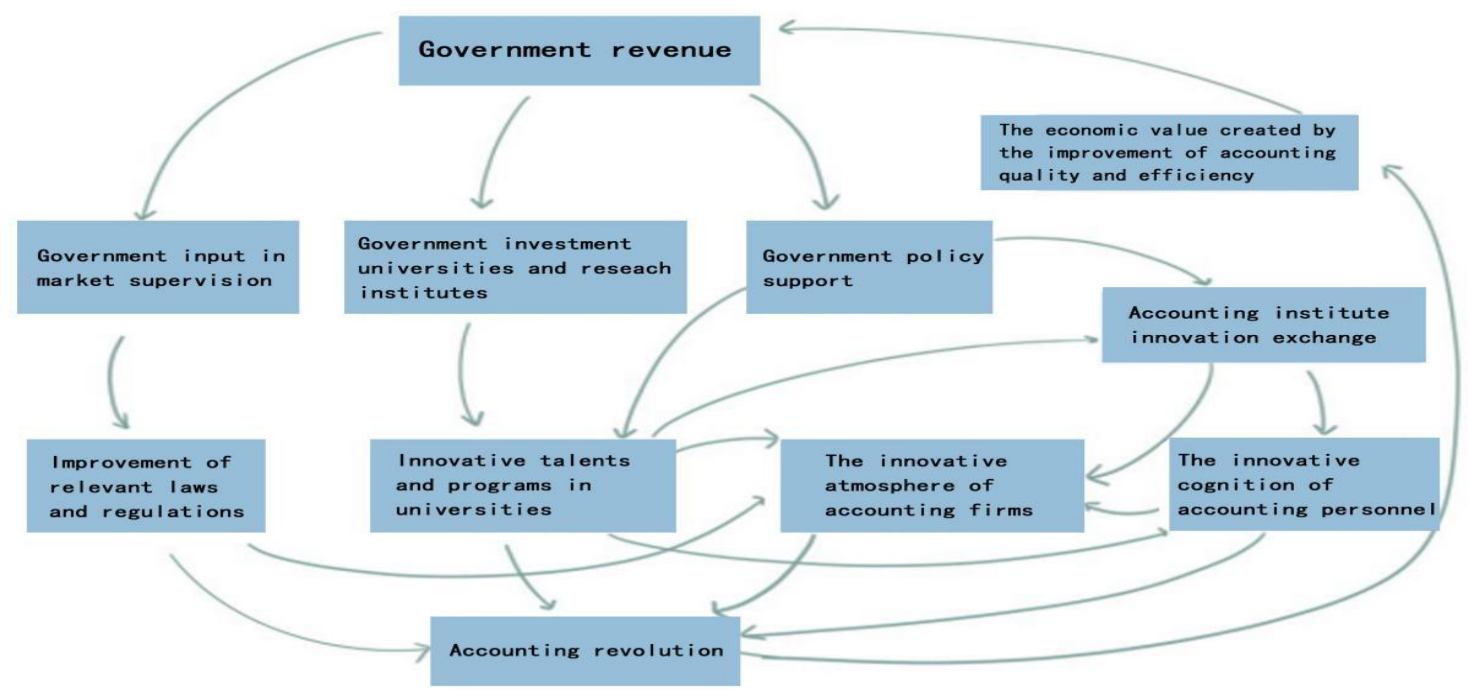

Figure 2 Feedback diagram of accounting innovation network dynamic system

\section{REFERENCES}

[1] Chen Donghua. System Innovation of Accounting in the Network Era: Property Right Definition and Marketization $[\mathrm{J}]$. AccountingResearch, 2000(02):52-56.

[2] Wu Taki. Innovation of Human Resource AccountingTheory 2008(10):31-36+96

[3] Xie Xuemei. Empirical Research on collaborative Innovation Network and Innovation Performance of smes [J]. Journal of Management Science, 2010 (8):51-64

[4] Wang Nong, Zhou Li, WANG Yue-hua, YAN Lijin, Wang Qian. (in Chinese) Research on the driving force of collaborative innovation in agricultural scientific research $[\mathrm{J}]$. Scientific management research, 2016, 34(01):91-92+120.

[5] Feng Qiaogen. Supply-side Reform and Management Accounting Innovation [J]. Friends of Accounting, 2016(07):128-133.

[6] Zhang Jingrui, Liu Xinling. Dynamic Mechanism and Path Choice of Collaborative Innovation of Ecological Agriculture in Fujian and Taiwan [J].TaiwanAgricultural Exploration,2017(02):1216.

[7] Guan Yamei, Xiang Huabin. On Accounting Innovation $[\mathrm{J}]$. International Business Accounting, 2017(04):71-73+87.
[8] Li Yujie. Research on Accounting Innovation in the Information Economy Era [J]. China Business Theory, 2018(33):136-137.

[9] GUI Liangjun, Zhou Yuhao, Chang Yeqing, Xia Xin. Accounting Theory Innovation and Practice under the New Development Concept -- Overview of the 2017 Annual Conference of Chinese Accounting Society $[\mathrm{J}]$. Accounting Research, 2017(09):90-92.

[10] Liu Zhenbin, Zheng Yifang. Research on the Driving Force System and Operation Mode of Collaborative Innovation of Agricultural Science and Technology [J]. Scientific Management Research, 2008, 36(01):73-76.

[11] Xia Bin, Wang Zhaoqun, Li Bingxiang, Wu Zuguang. Accounting Innovation in the New Era of High-quality Economic Development -- A Summary of the 25th Annual Conference of The Chinese Accounting Association Branch of Engineering Colleges [J]. Accounting Research, 2018(11):95-97.

[12] Li Zhijian, Yin Chunyang, Yang Baojun, Geng Jianxin. Basic Theory System and Innovation of Accounting -- Overview of 2018 Academic Seminar of Professional Committee of Basic Theory of Accounting of Chinese Accounting Society [J]. Accounting Research, 2018(12):92-94.

[13] Sun Zheng, Liu Fengwei. Reform and innovation are the main melody of the future development of 
accounting [J]. Accounting Research, 2019(01):512.

[14] Ding Shenghong, Wu Yingyu. Discussion on management Accounting Theory System and Measurement Method Innovation based on humanistic Economic Development concept [J]. Accounting Research,2019(01):53-58.

[15] tian gaoliang. Research on the development of accounting service industry in the construction of "One Belt And One Road" [J]. Friends of Accounting, 2019(01):2-6. 